\title{
KULA THE NURSE AND NUA THE TEACHER: TOKELAU'S PROFESSIONAL PIONEERS
}

\author{
JUDITH HUNTSMAN \\ University of Auckland
}

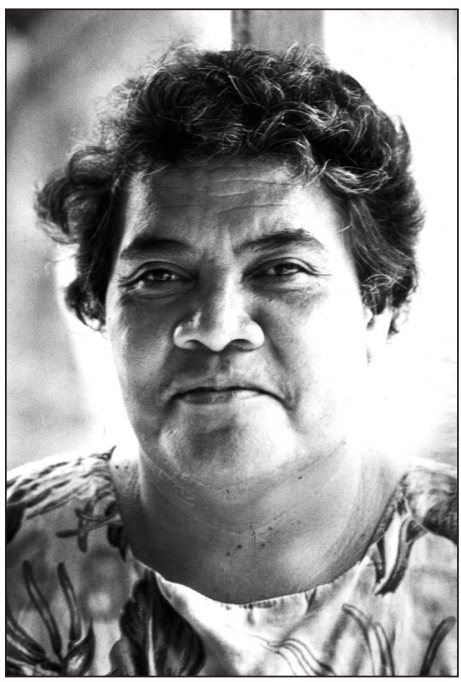

Kula Fiaola 1924-2003

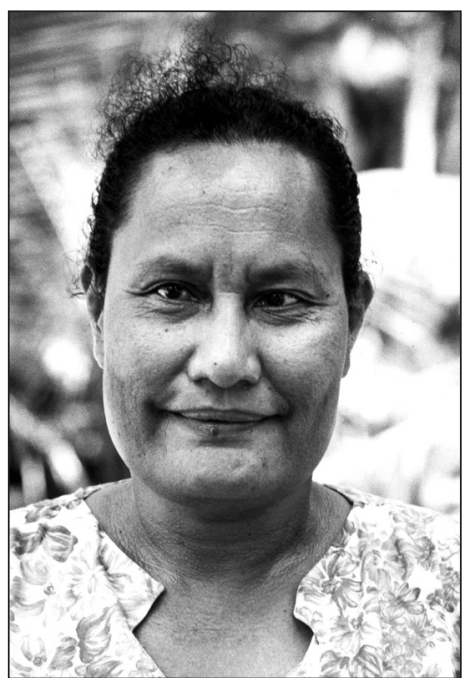

Nua Mamoe 1924-2007

The atolls of Tokelau, named Atafu, Fakaofo and Nukunonu, are located north of Samoa, east of Tuvalu, west of the northern Cooks and south of the Phoenix Islands (now part of Kiribati). They were never considered worthy of much attention by metropolitan powers, and were remote and difficult to get to. Being atolls they are tiny and resource poor. Being "true" atolls they have neither passes nor secure off-shore anchorages. In the mid-1800s the atolls were severely depopulated in the interests of conversion: 500 were removed to Uvea by the Marist mission in 1852 (Huntsman 2004) and the London Missionary Society knowingly allowed virulent dysentery to enter Fakaofo in their eagerness to install a Samoan teacher there. On top of these depredations, over 250 were carried off to Peru in 1863 (Maude 1981, Huntsman and Hooper 1996: 204-10). Those that remained in Nukunonu were Marist Catholic, those in Atafu LMS Protestant, and those in Fakaofo 
of both these Christian persuasions. By the turn of the century, the Tokelau population had grown from 200-300 in 1863 to nearly 1000, the Union Jack had been raised on each atoll and each had thereby been brought under British protection, and the three atoll villages had adapted their pre-contact institutions to their new circumstances. Tokelau was, and would continue to be, three virtually autonomous, staunchly egalitarian polities.

For 36 years Great Britain tried to oversee these most remote places through the Western Pacific High Commission via its deputies in Samoa and Tonga (1889-1909), and then as appendages of the Gilbert and Ellice Island Protectorate (1910-1915), and finally as part of the Gilbert and Ellice Island Colony (from 1916). Oversight was tenuous and administratively unworkable because of the absence or uncertainty of transport. So it was that in the early 1920s the Colonial Office in London decided to persuade the New Zealand Government through the office of New Zealand's Governor General to assume administrative responsibility on Great Britain's behalf for these central Pacific atolls they called the Union Islands. From London this appeared a simple, straightforward solution to a long-standing problem since New Zealand already administered nearby Western Samoa under a League of Nations Mandate. Nonetheless, the negotiations were protracted and involved other parties and interests. Nothing of these negotiations were made known to the inhabitants of the Tokelau atolls, yet when they were finally appraised of the new arrangements in 1925, the Tokelau people pronounced themselves satisfied because they would allow them easy access to Western Samoa. From the Tokelau point of view, their colonial linkage with the Gilbert and Ellice Islands had compromised their access to their Samoa-based missions and the educational opportunities they provided, and to colonial port town employment. The New Zealand attachment did not solve administrative problems, which were exacerbated by the Depression and the Second World War, and not until after the War, in a very changed colonial climate, did the New Zealand Administration give any thought to establishing schools in Tokelau or to improving the very elementary health services. ${ }^{1}$ When these thoughts were implemented and plans were afoot the New Zealand officials discovered that there were educated and professionally-trained Tokelau people in Samoa who could set up and serve these new institutions. They were people who had taken advantage of the access to schooling that Tokelau's administrative linkage to Samoa had given them. ${ }^{2}$

Prominent among them were two women, both born in Tokelau in 1924, whose families, and particularly their fathers, had enabled and encouraged them to take advantage of opportunities for education. These women had excelled at Samoan schools and had been urged by their parents and other Tokelau people to pursue professional training. Both returned to their 
homeland to initiate changes, to give decades of dedicated service and to be exemplary role models for others. In Tokelau they have long been celebrated for their devotion to the welfare of their compatriots, but neither was adequately rewarded for her professional achievements, for those who made such decisions were not Tokelau people but New Zealand officials who had peculiar ideas about the intrinsic abilities and merits of women.

In Tokelau culture women are valued not only as mothers and nurturers of the next generation but also as fatupaepae, literally 'foundation stones', of the many extended family corporations (käiga) that comprise the villages. Women's roles in their families as sisters are complementary to those of men as brothers. They customarily remain in their natal homes after marriage to manage internal family matters, including the equitable allocation of family resources within the family, especially to their brothers, who reside in their wive's family homes but continue to provide fish and produce for their natal family and as elders to represent that family's interests in the village council. In a succinct characterisation: women reside and divide; men provide and decide. ${ }^{3}$ While it is the duty of brothers (and men in general) to protect their sisters (and women in general) from danger, it is the responsibility of sisters (and women in general) to give refuge to their brothers (and men in general) in distress. Women are not considered of intrinsic less worth or to have less ability than men.

The two women, whom I portray here, were considered as worthy and able as their brothers by their parents and as their male colleagues by their Tokelau compatriots. They are no longer serving Tokelau as nurse and teacher, and those they inspired and mentored have taken their places, yet they are still celebrated as Kula the nurse (died 2003) and Nua the teacher (died 2007). Their stories are similar in some ways and complementary in others, and I record them here, though not exactly as they told them to me. ${ }^{4}$

\section{KULA THE NURSE}

On the 30th of April 1924, a baby girl was born to Kula and Fiaola in Fakaofo, and she was named Kalapu. Fifteen years later, her name was changed to that of her mother by the decree of a teacher at the mission school in Samoa because there was another girl named Kalapu at the school. Though thereafter she was Kula to everyone, she signed her name K. Kula Fiaola s.n.- the K. for her original name and the s.n. for staff nurse.

Kula was brought up in the family homestead of her mother's extended family, her father having moved there at marriage following usual Tokelau practice. Her mother had replaced her own mother as the fatupaepae 'foundation stone' of that family. She had "remained inside the family" while her brothers had "gone outside" to their wives' homes at marriage. Yet, her brothers, and 
her own mother's brothers, brought fish from the sea and produce from the plantations for her to keep and allocate, and she looked after her elderly mother and her brothers' children. The family were devoted Christians and staunch members of the LMS Church. Three of her mother's brothers were missionary pastors and the other two were local deacons; one sister was a pastor's wife while the other two were wives of deacons. That Kula became a devoted Christian too is not at all surprising. However, her mother had a more marked influence on her later life in another respect. She was extremely meticulous in everything she did: in plaiting mats, in cooking, in maintaining the family homestead; and she provided generously for visitors to or guests of the village. Kula's skills and behaviour as a nurse conformed to her mother's practice. Indeed, Kula recalled that in the days of her childhood, well before there were any trained nurses in Tokelau, when locally recognised midwives assisted women in childbirth, her mother's specific role was to clean and bandage the umbilical cord of the newborn. Given that septicaemia of the umbilicus was the most prevalent cause of infant deaths, her mother's role was crucial - and in later years Kula would perform the same role as part of her nursing duties.

The family of her father, Fiaola, while equally firm in their Christian belief, did not have the staunch devotion to the LMS church that her mother's family did. Kula was not as close to her father's family as to her mother's, yet her father was perhaps a more significant figure in her life. He was a very wise and thoughtful man, though, like most of his generation, he had no "proper" schooling. He was an extremely skilled fisherman and a close friend of the Tokelau doctor, Logologo. ${ }^{5}$ Fiaola continually gave encouragement and support to Kula, at the same time allowing her to make her own decisions.

Her father's and her mother's widely extended families gave Kula an extensive network of kin in Fakaofo and beyond. Her father's family was truly pan-Tokelau because his grandparents had land rights in all three atolls, and established estates for their children in each. Though these lands were held and harvested by fourth and fifth generation descendants of the original couple, the three local branches retained a strong sense of kinship and the obligations that constitute it. Kula's acknowledged rights and the obligations that her kin on her father's side fulfilled meant that, though she was born and raised in Fakaofo, she was a pan-Tokelau person.

In Kula's childhood years schooling in Tokelau was left to the missions and Protestant children attended the pastor's school where they studied the Bible and learned to read and write Samoan. What else they were taught depended how the pastor and his wife had been schooled, and in the later 1930s Fakaofo's pastor was quite well schooled and valued education. When he and his wife proposed to take some boys and girls from Fakaofo for further education at the LMS mission schools in Samoa (Papauta for girls 
and Maluafou for boys), Kula's parents decided that she must go. So Kula entered Papauta, together with a cousin, in March 1939 and five years later, in November 1943, having proved to be an excellent student, she was urged to take an entrance examination for a profession.

What might her profession be? On the one hand, her parents had not intended that she be schooled to become a pastor's wife, which was the aim of many parents who sent their girls to Papauta. On the other hand, they left the decision to her. For young women there were really only two choices: nursing and teaching. Kula had wanted to be a teacher, but her missionary teachers urged her to train as a nurse, and so did a prominent Tokelau man working at the LMS Printing Works. So, at their urging, she took the examination for entry to nursing training and to her own surprise passed it. She had doubted that her English was good enough.

In early 1944 she left the Tokelau household where she had been living and went to stay at the Central Hospital in Apia. All of the staff involved in nursing training were papālagi (from overseas), as were all those who held senior positions at the Hospital. Samoan doctors and nurses were usually assigned to district hospitals. Kula vividly recalled one of her teachers, a midwife named Sister Duggan. She was a very skilled nurse, and also very strict, often almost terrifyingly. In some respects she was a model for Kula. For example, Sister Duggan would gently, but sharply, slap the buttocks of women in labour, this tactic was to make them concentrate on what they should be doing and not dwell on the pain that they were feeling. Kula regularly used this tactic in many of the hundreds of deliveries she supervised. In later years, younger Tokelau nurses who just completed their training and were under Kula's supervision recalled how shocked they were at her practice. Kula would explain that this was an effective and proper tactic with women who knew you well, and trusted you, but it was not something you did to strangers. Certainly, Tokelau women trusted Kula, felt safe in her hands, and apparently never felt abused or ill done by. Other nurses were, nonetheless, reluctant to so belabour women in labour.

Nursing training, while including lectures and textbook reading about signs and symptoms of particular illnesses, consisted primarily of practical, hands-on experience in the Hospital. Kula was to have more direct experience than most. In 1946 there was a serious flu epidemic throughout Tokelau and Kula was sent with a Samoan doctor to Tokelau, where she remained for three months until the epidemic was over.

After three and half years training and passing her last examination in mid-1947, Kula became a certified nurse, but she did not immediately return to Tokelau. She was assigned to nurse at two district hospitals in 'Upolu, and later at the Central Hospital. 
During her last year nursing in Samoa, Kula married a Samoan doctor and the following year (1951) her son, Logotasi, was born. Kula had regularly stayed with Samuelu and Naomi, a Fakaofo couple who had established a home in Samoa and were surrogate parents for many Tokelau young people schooling or training in Apia. Kula continued to live with Samuelu and Naomi after she was married, her husband joining the household when he was off-duty, and Naomi took care of Logotasi when Kula returned to work.

This arrangement did not last long, however; in 1951 Kula and her husband were sent to Fakaofo, her husband to be the doctor and she the nurse. It seemed a perfect arrangement, but it was not successful. Her husband found it difficult to conform to Tokelau expectations and, after serving briefly in Atafu and Nukunonu (while Kula remained in sole charge at Fakaofo), he left Tokelau. His departure in effect ended their marriage. Thereafter, Kula's three commitments were her nursing, her son and her wide family, all of them bound up in her devotion to Tokelau.

Kula was the first qualified Tokelau nurse and the third qualified health professional in Tokelau history. The other two were known officially as "native medical practitioners" and had trained in Fiji in the 1910s. One of them served only briefly in Tokelau, but the other, the aforementioned Logologo, known in Tokelau as "the Doctor" began tending to Tokelau ills in 1917. Otherwise medical services were provided by "dressers" who, befitting this papālagi designation, dressed sores and wounds, but also dispensed patent medicines, e.g., Epsom salts, castor oil or aspirin, in keeping with their Tokelau designation as tala vai 'dispensers of medicine'. All of them were men, who had been trained in Funafuti (Tuvalu) and were counselled from time to time by the itinerate Dr Logologo. In each atoll, certain mature women were renowned locally as midwives and Dr Logologo counselled them too, but they received no pay and had no official position. At least in Fakaofo there were nurse aides, again unofficial and unremunerated, who bathed and tended the sick. Logologo had retired before Kula returned to Tokelau. Right through the 1950s the presence of doctors in the atolls was erratic. The Annual Reports of the era present the health services as follows (this 1956 report was repeated almost verbatim annually):

The medical services of the Group are administered from Western Samoa, and regular visits to each atoll are made by European medical officers. A Samoan medical practitioner is now stationed at each island.... Other medical staff, consisting of nurses and dressers, are distributed throughout the Group. All these personnel obtain their training at Apia Hospital in Western Samoa. The standard of training of the medical staff is sufficiently high to cope with the great majority of cases, but if additional advice or instructions are needed these are quickly and efficiently provided by means of the radio service. (Appendix to the Journal of the House of Representatives 1957, A.3: 115) 
The actual situation was rather different from that reported. The visits by European medical officers were hardly regular, Samoan medical practitioners may have been stationed but they were not present, only one nurse was "distributed" to the Group-Kula in Fakaofo. On one score it is accurate: her training was high and she did cope with many cases. Her own dramatic account of one of these cases (my translation) highlights the misrepresentations above. ${ }^{6}$

A man in a temper - piqued because he felt he was not receiving his fair share of food - seriously cut his own arm an inch or so below the elbow with a bush knife. He had cut himself very deeply_ severing an artery so that the blood gushed out and even cutting into the bone. I tried to stitch it up, but it was too late to close the wound. In the event it became septic and I wired Samoa for help. It was arranged that a doctor would come up from Samoa to deal with it —on the Joyita. But the Joyita never arrived. ${ }^{7}$ As the days and weeks passed the infection became worse and worse. The smell of putrid flesh was overpowering and put the poor man completely off his food. Something had to be done soon, so I again called the doctor in Samoa for advice, and he said that I would simply have to do what I could. I knew that only surgery would save the man from dying of gangrene poisoning.

I went to the Pastor for counsel and he advised me to leave it be (tuku $v \bar{e}$ - - after all it was the man's own foolishness that had brought this upon him, and further he was concerned that if I did anything and something went wrong I would be blamed for whatever happened - blamed because I had assumed to be skilled like a doctor. Truly he was very concerned for me, lest something untoward occur.

Then I spoke to my father and he said that he would pray. If it was the will of God that the man could only survive because of my intervention, then I had to intervene. 'What you need to do, you do,' he said. I agreed with my father.

I thought about what I would do. I humbled myself before God. I would not take the patient to the room where operations were usually done by doctors, but to the thatched ward where nurses look after patients. My father remained outside praying, and told me to go ahead. I knew I was not a doctor but I knew that God would guide me. I said to the man's mother: "Are you confident?" She replied: "Kula, I believe that the Lord will assist you." My father said: "Go ahead."

We prepared everything and I believed that he would survive. With two dressers in attendance, I gave a local anaesthetic. I went ahead, I was not anxious. I had been anxious but God reassured me. He led me. It was really not difficult at all - just as if I were a real doctor. No one told me how to do it, I just did it.

The cut was on the inside of the arm and here the infection had begun and spread quickly. On the outer side it had not spread as rapidly, and fortunately the infection had not spread as quickly up the arm as down. I cut through the bone at the elbow joint, scraped away the rotten flesh and carefully cleaned the 
remaining flesh and skin with antiseptic. Then I flipped the cleaned, healthy flesh and skin over the elbow stump and sewed it in place. After it was done I wired Samoa to inform the doctor that it had been successful.

There was no difficulty, it was easy. Really my father, and also the pastor, helped. The pastor was genuinely concerned that I would be blamed if something went wrong. But more important was the faith and support of my father.

The Nurses Association in Western Samoa acknowledged her outstanding nursing by giving her their Awards Cup the same year. Kula's surgery patient in time became a Fakaofo elder and a member of the village elders' council.

This story was not just Kula's story; many others told it. It was a testimony of their trust in and admiration for her. They recognised her devotion to their well-being, her dedication to her profession and to Tokelau. There is no account of the event in official reports. There are other stories to be told in Kula's nursing career, but none nearly as dramatic as this. More important, however, was Kula's constancy, her enduring concern for people's well-being manifest in her regular nursing practice. Hundreds of Tokelau babies were delivered into her hands, and some of these babies became mothers themselves under Kula's guidance. She dealt repeatedly with flu outbreaks when just about every villager was ill and more often than not the promised medicine to alleviate their symptoms did not arrive until they had all recovered. She managed hospital wards packed to overflowing with children and adults suffering from highly infectious diseases like hepatitis, measles and chicken pox. ${ }^{8}$ She bandaged and dispensed medication in clinics day after day. And she rigorously trained numerous young women who were inspired to become nurses by Kula's example. Before they went to Apia for formal training she instructed them as nurse aides and upon their return to Tokelau she mentored them as staff nurses. The training regime for nurse aides was strict, and was transmitted in sharp precise instructions at some distance. I recall Kula reposing in the Fakaofo nurses' house, apparently engrossed in a game of patience or in the fierce competition of a game of cards or dominos (she was an avid card player and had a set of dominos that went to double-twelve) yet alert to everything that was going on around her. A loud chirp to a nurse aide at a considerable distance would be followed by a command to attend to something, or bring something, or do otherwise than she had been doing. Those that passed Kula's training regime, and became nurses like her, share her pride in doing things properly. As of the late 1990s, eight of her Fakaofo nurse aides became qualified nurses and five of them were still serving. She instilled in them a strong tradition of pride in their work and in their hospital.

Although Kula nursed throughout Tokelau, Fakaofo was her home. There she reigned over the Papa, a reclamation on the reef flat some metres 
northwards of the village proper where Fakaofo's hospital - a dispensary, doctor's office, wards and nurses quarters - was located. Built in the 1930s, it was a place of great local pride, and literally a Fakaofo creation. It was a place separate from the village, clean and private, where no children were allowed unless they were patients (because, said Kula, kids can be naughty and cause accidents), where the breezes revived the ailing and infections were isolated from the village. Kula provided succour to the concerned and ill, but took no nonsense from anyone. The hospital rules were strict and charge nurse Kula a stern disciplinarian. A younger nurse recalled Kula sending people away from the Papa because they had come to the Hospital not bathed and cleanly dressed. If one came for treatment, one should have bathed and attired oneself in clean clothes, unless of course it was an emergency.

After six or so years in Fakaofo, Kula was transferred to Nukunonu, probably because there was no doctor there and a Tokelau doctor had been placed in Fakaofo. For over a decade she was shifted repeatedly between Nukunonu and Fakaofo (with one brief stay at Atafu) as her services were needed - again often because there was no doctor and her firm and experienced hand was needed to take charge of the local health service. ${ }^{9}$

Wherever Kula was in charge, the Women's Committee became active, keeping the village swept and clean of rubbish, keeping an eye on the welfare of children, and conducting ahiahi 'visitations' to see that all homes were in order. Though officially under the auspices of the doctor and the leadership of the wives of the two elected village officers, in Nukunonu and Fakaofo it was more often Kula's presence that activated the Committee. ${ }^{10}$

When she was first in Nukunonu, in the late 1950s, Father Alex McDonald was the priest there. He was a teacher himself and advised her and made arrangements on her behalf for Logotasi to attend the Marist Brothers' School (A'oga Felela) in Apia. So in 1960, when Kula went for a refresher course in Apia, she enrolled Logo at the school, where he continued right through his secondary school years, staying as he had as a baby with Samuelu and Naomi. Samuelu was not happy about Logotasi receiving a Catholic education, but Kula insisted on him attending the Catholic school, trusting the advice of the priest. ${ }^{11}$ Her faith in the priest's advice turned out to be well founded. Logotasi did very well and was awarded a Tokelau scholarship for further education in New Zealand. Kula requested a period of leave to spend time with him in Samoa before he left and to witness his departure. In time he fulfilled his mother's highest hopes: graduating with a Master's degree from university, gaining a senior position in the New Zealand public service, and later putting his experience and expertise in the service of Tokelau, supporting his mother's extended family and establishing his own family-including, of course, a daughter named Kula. 
As well as her son, there were many children who came to call Kula mother. The older children of her mother's brother's daughter, who was raised as Kula's sister, called her mätua 'mother', as children normally call their mother's sisters. She told of how one of her tama 'sons', upon completing his dentistry training in Fiji, returned to Fakaofo, and, in keeping with what he had learned abroad, repeatedly urged the women who smoked to quit-Kula among them. The women resented the persistence and insistence of this young man telling them what to do, but Kula, to set an example, stopped smoking.

Kula's compassion for the unfortunate was fully expressed by how she came to care for her "other children". First, there was the infant conceived under unfortunate circumstances that no one really wanted. Kula delivered the baby and took her as her own-arranging for new mothers to be wet-nurses and herself feeding the child powdered-milk substitute and the jelly-like meat of the young coconut. Then for years she succoured and tended a severely disabled boy, making sure that he had whatever opportunity could possibly benefit him.

Many people, speaking about Kula, recalled her deep compassion. She frequently passed nights wide-awake, alert to the needs of a person who was ill. One man remembered her sympathy for his severely disabled child, and how she would stay up nights caring for the child when she was very ill so that his wife could get some rest.

Although Kula officially retired in 1984 or 1985, she continued working. Her actual retirement was delayed for two related reasons. A new hospital had been built on an islet some distance from the main village of Fakaofo. There were not sufficient staff nurses to tend a dispensary at the Papa and run the new hospital, but it was absurd that people picking up daily medication or in immediate need of minor medical attention should have to travel by motored runabout 15 minutes or so (depending on the sea) to THE hospital. So Kula again took charge of the Papa-or more precisely half of it because the new local administration and wireless offices occupied the other halfand from there dispensed drugs and dealt with minor complaints. This was until 1987, when a cyclone demolished the reclamation that had stood for 50 years, and the dispensary was shifted to a substantial structure right in the village on a reclaimed section at lagoon shore. Then in 1990 yet another cyclone with very severe storm surges demolished that reclamation and the structure upon it, and the dispensary moved yet again to the upper level of a village house (the administration office had been shifted to the lower level after the earlier cyclone).

Kula wrote in her own brief account of her life (in the Fakaofo local newspaper) noting that as of "24/4/90 I rested for the first time from the work of being a nurse and am in the family", but this is not exactly true. She 
did indeed reside in the family homestead, yet she still went to the upstairs dispensary to tend to the residents of Fakaofo. Only in 1992 did she finally retire when she went to New Zealand to join Logotasi and his family. Counting from Kula's earliest, though brief, service in Tokelau in 1946, when a flu epidemic raged, to 1992, when she left Fakaofo to really retire, her nursing career spanned 46 years. Kula, reflecting on her years of nursing, remarked:

People must trust nurses and doctors at the hospital, and they obey their instructions because of that trust. In the old days, perhaps we did not think very fast, but we did things properly and carefully. Things have changed. Now people think fast, have a lot more knowledge, but they do not do things properly.

I rather suspect that the new hospital — modern as it may be - sums up Kula's disquiet. The hospital on the Papa was a refuge, a place of order and control, where things were done properly.

Repeatedly it has been asserted: "The staff nurses... are really capable of doing their duties in the absence of a doctor" (Matagi Tokelau 1991: 172). In Kula's case, she showed herself capable of fulfilling many duties of a doctor, but for this she was never officially recognised in status or pay. In 1975, her annual salary after 24 years of service was less than half that of a Fiji-trained doctor who had recently qualified and had less than three-year's service.

In 1982 Kula was awarded a New Zealand Queen's Service Medal for Public Service for which she was grateful without pride. Her pride was in having had the opportunity to serve her people as a nurse and in having inspired others to do likewise.

\section{NUA, THE TEACHER}

Nua was also born in 1924 on the 3rd of November in Atafu, the fourth child of Lepaio and Aga. Lepaio, as a bright young man, was selected for training as a medical "dresser" and spent some time in Funafuti, but his marriage put an end to his training and this career. Four years after Nua was born he decided to see if he could find a job in Samoa and Aga went with him, leaving Nua in Atafu with Veronika and Nikotemo. Lepaio came to be employed by the New Zealand Administration as a warden at the Tafaigata prison. With this job went a house near the prison and this house became the home away from home for numerous Atafu young people at school or working in Samoa.

In Atafu Veronika and Nikotemo were quite simply Nua's "parents". They looked after her even before her birth parents went to Samoa, just as they had looked after her mother, Aga. The explanation is a bit complicated. Veronika was the child of a Samoan chiefly family from Vaimoso, a village on the outskirts of Apia. She had come to Atafu in the 1890s as the wife of 
Daniel Jennings, ${ }^{12}$ who was a trader. After Daniel's death, Veronika married Nikotemo, and continued to run her former husband's business that was licensed in her new husband's name. Her enduring reputation is summed up in the name Atafu bestowed upon her, Talitigā 'Comforter of the Distressed'. Veronika had no children of her own, but raised and mothered many. Aga was probably the first, since she was related to Daniel. ${ }^{13}$ With her marriage to Nikotemo, Veronika gained two more children: his youngest son by his former wife and his sister's youngest son. In later years, together they cared for several children of these earlier children, including Nua.

Nikotemo was appointed Atafu's Faipule (official responsible for local administration and law enforcement) when New Zealand officially took over Tokelau's administration in 1926 and remained Atafu's Faipule until his death in 1949. He was an intelligent and able man, and had some fluency in English. He and Dr Logologo were fast friends. Logologo usually brought along his eldest son when he visited Nikotemo. Nua told this story of one of these visits.

Nikotemo and Logologo were inside talking, not wanting to be disturbed, so
the doctor's son and I were outside with my mother's two 'brothers'. They
goaded me to wrestle with the doctor's son because he was strutting around and
acting pretty tough. They worked me up to challenge him and he responded,
slapping his upper arms in the customary challenge. My 'mother's brothers'
then directed my movements, shouting out for me grab his neck and choke
him, to throw him to the ground, and finally to throw him into the pile of ash
and cinder from the earth oven. I did throw the poor boy into the ashes to the
great delight of those two.

Nua found this incident of her childhood particularly memorable because of her later collegial relations with the same doctor's son during the many years that they were both teachers at the Atafu school.

Nua attended the Atafu pastor's school, where she reached the second level. She was rather sickly as a child, suffering from a mysterious 'recurring ailment' (tauale oho) in her stomach. During her 12th year, her illness became more severe and once she was so seriously ill that her family called for the pastor, fearing that she was dying. All her parents - those in Atafu and those in Apiaagreed that she must go to Samoa 'to seek a remedy' (hakili he togafiti) either papālagi or Samoan. This was 1936 and a major change in her life course.

Enroute to Samoa the ship stopped in Fakaofo, and there she encountered relatives on her mother's side. They were rather taken aback because she did not regard them as kin. She thought that her family were only Nikotemo and Veronika, and her two 'brothers'. Then again in Samoa she was miserable, crying night and day for her "parents" in Atafu, even though she had come to stay with her birth parents. Her homesickness only abated when some 
Atafu young people, attending school in Apia, came to stay at the house near the prison. Her parents sought explanations and remedies for her illness everywhere. They went to doctors at the hospital, but they could find nothing wrong with her. They went to traditional Samoan healers, but they too were of no use. Yet they persisted and their persistence was finally rewarded. A Samoan doctor stationed at the district hospital outside Apia diagnosed what it was and prescribed some pills and after four months her ailment disappeared, never to recur.

Her father Lepaio was well regarded by Samoans and New Zealand officials alike. At the time of the Mau uprising this Tokelau prison warden had given sympathetic consideration to the imprisoned Samoan activistsmany of them matai of considerable eminence. The Samoans in appreciation bestowed a title upon him, and Nua recalled that their household was always well provided for by Samoans who were grateful to him. The New Zealand officials found him to be a conscientious and reliable employee and granted him the same privileges as their Samoan employees, which meant that his children were eligible for government schools and scholarships.

Consequently, when Nua had regained her health, Lepaio enrolled her in the government school at Malifa, even though she was already about 18 years old and had only had mission schooling. She had to start at a lower primary grade, but she was quickly promoted and soon completed her primary education at Standard 2. Then she took the government examinations for admission to secondary school. These were crucial examinations that determined whether a child would be eligible for any post-primary schooling. Shortly after she took the examinations, Lepaio became ill and she stayed at home to care for him. By the time he had recovered the school year had begun, and, when she tardily appeared at the Malifa Girl's College, she was told that there was no place available for her. Actually, another had been put in her place; the opportunity had been taken to deny a place to a Tokelau girl in favour of a Samoan (lotoleaga auā hē he Samoa 'out of spite because not a Samoan'). When she told her father, he would not accept the situation and went straight to the papālagi missionary in charge, who called for Nua's files only to discover that her grades on the examinations were right at the top. She went to Malifa College for Girls for three years - again advancing rapidly through the classes, and ended her secondary schooling at Form 4.

The time had come for her to select professional training and to take the appropriate examination. She wanted to train at the Hospital, and Kula, who was already in training, encouraged her. Though she passed the qualifying examination, she was rejected for nurses' training because of a minor disability, the consequence of an injury she suffered some years before, giving her limited vision in her left eye. ${ }^{14}$ When she was not accepted on medical 
grounds for nursing, she took the examination for teacher training - her other option - and began training as a teacher the following year. This twist of fate was to be of vast benefit to her homeland.

An officer of the New Zealand Department of Education had gone to Tokelau to review the education situation a year or two before, and had spoken with Nikotemo and Veronika. They told him about their "daughter" who was training as a teacher in Samoa. Then Nikotemo, while visiting Samoa on the invitation of the Samoan Fono Faipule in 1948, had signed a bond committing Nua to serve as a teacher when she completed training.

After the aforementioned review the New Zealand Administration undertook to establish tulagalua or government schools at Fakaofo and Atafu, ${ }^{15}$ and they went in search of teachers to go to Tokelau and set up the schools. In late 1950, when Nua had completed only two years of teacher training, she was assigned to go to Atafu along with Sofi Pua, an experienced Samoan teacher. Ropati Simona, a Tokelau man born of missionary parents in Papua, who had been head teacher at the Samoan model school, was assigned to Fakaofo, along with Ioata Tanielu, whose mother had been born in Atafu and who was a teacher trainee in the same class as Nua. Sofi and Nua in Atafu, and Ropati and Ioata in Fakaofo, were to establish government schools and teach all the pupils. Ropati, the most senior and experienced, was the head teacher overall.

Although Nua may have had some reservations about taking up this difficult job with only two years training, she felt a strong obligation to return to Atafu not just because she was bonded to teach, but to satisfy all her parents who had such confidence in her ability. Furthermore, Nikotemo had died the year before and Veronika was still in Atafu.

Nua, with the other pioneering teachers, voyaged to Tokelau in early 1951. The task before them was daunting. The pastors' schools had been atoll institutions for almost a century, and their programmes and procedures were quite different from those intended for the new government schools. Children began attending the pastors' schools from the age of three and many continued to attend right into their twenties, or until they married. The pupils progressed through six levels, being promoted not as they became older but as they passed set examinations. This meant that students of varying ages were at the same level. Teaching focused on the Bible and on Samoan language as the language of the Bible and the church. Some maths were taught and perhaps a bit of English, if the pastor had the ability. Aside from the Bible, there were no texts or teaching materials, and there were no proper classrooms.

The government tulagalua schools were supposed to have graded classes in which the students were of comparable age and achievement. Children were expected to begin attending school at five or six years and to leave school 
well before they turned twenty. Bible study was not part of the curriculum but Samoan language teaching was necessary since all the teaching materials brought up from Samoa were in Samoan or English. The basic subjects taught were social science, maths and English phonics.

The changes could not be made instantaneously. Nua and Sofi divided their pupils into two groups - based on both age and previous achievements. To establish who was in which grade, she and Sofi had initially constructed a rough test and then promoted the older students as quickly as possible when they acquired basic skills. They could only slowly undo the pastors' school model, and it was not really until years later that grade level and age became aligned. Nua taught the lower/primer division, aged approximately 6-12, divided into three grades, at the village meeting house, and Sofi took the upper/tulagalua division, again divided into several grades, at the church meeting house in the pastor's compound. These were indeed "composite classes". They had to improvise, to work out for themselves a manageable teaching programme. For the primers, Nua explained: "All the materials and programmes came from Samoa, the workbooks came from Samoa - everything came from Samoa. I tried to teach in Tokelauan. I would read to them in Samoan and if they did not understand I would translate into Tokelauan."

One aspect of the pastor's school was retained; school hours were from 8 am to $1 \mathrm{pm}$, which accommodated the pastor's school held in the late afternoon, from about 4-6 pm, so that students could continue to study the Bible.

The village enthusiastically supported the new school. The pastor and his wife assisted the two teachers, and so did the local radio operator. The parents gave strong support and things moved along quickly. When inspectors came from Samoa they were impressed with their progress. Nua's explanation for their success was that the children were very bright, and she cited names of her early pupils who succeeded and became nurses and teachers. These pupils, in turn, would give credit to Nua for their success.

For all this work, Nua received a salary of $£ 10$ each month and Sofi received $£ 20$. The village was a good deal more generous to their teachers than the Administration was to their employees. Nua and Sofi were accommodated and provisioned by the villagers in much the same way that pastors were. Sofi lived in the pastor's compound, and Nua, though she stayed with her family, ate at the pastor's house. With the arrival of later teachers this practice was gradually discontinued, and the teachers in time came to be regarded as fellow villagers, which indeed they were. For a while they continued to receive special portions when fish and produce was distributed village-wide even when school was in recess, then only the head teacher received a special portion that he shared with the others. Finally, they were simply counted within one of the village share units just like everyone else. ${ }^{16}$ 
Sofi taught in Tokelau for four years, and in the last year went to Fakaofo while Ioata came to Atafu. ${ }^{17}$ Before that school year began, Nua and Ioata were summoned back to Samoa to graduate in the class with which they had entered Training College. They may have had fewer years of teacher training, but then they had much more practical experience. They certainly had far more experience than the newly trained teachers who were assigned to Atafu - the first in 1953, three more in 1954, and two in 1957. All of them were men born in Atafu who had attended secondary school in Samoa and had been recruited to train as teachers. ${ }^{18}$ It was not until 1958 that another woman joined Nua. She was the sister of one of the teachers and he had told a visiting school inspector that his sister was a Samoa College graduate, training as a teacher. The inspector virtually commanded her to go to Atafu as a teacher of oral English, particularly at the upper levels. Further women teachers were finally appointed in the early 1970s. Two of them were trained as primer teachers. At last, after nearly two decades during which Nua alone had taught all the primer classes together in the village meeting house, the three classes had different teachers and separate classrooms. Nua took the third, most advanced class.

Elia Mamoe was one of the teachers who started teaching in Atafu at the beginning of 1957. It was not long before he asked Nua to marry him, having already made a good impression on her older sister and her husband, with whom Nua was residing and who were looking out for her. Nua initially rejected his proposal. But Elia persisted and wrote to Lepaio and Aga in Samoa. Lepaio radioed to Nua wanting to know what this was all about. Nua was dumbfounded. Elia had sent the letter without her knowledge. With widespread approval she agreed to marry Elia on the condition that her parents came to Atafu for the wedding. However, the scheduled ship on which they had arranged to voyage to Atafu did not appear in Apia, and, in the event, they were not in Atafu to see Nua wed.

By the end of 1961 Nua was the mother of four children: three boys and a girl. With each child she took three weeks off and then the infants were left with either her sister or Elia's parents while she was at school. Elia's parents' house was only a few steps away from the meeting house where she still taught the primer classes, so at recess she could feed them. Nua explained that she simply could not 'abandon her job' (tiaki te galuega) because who else was there to do it. Furthermore, she never took a day's sick leave during her whole 34 years of service. Her dedication to the school she began, her loyalty to her village and especially its children kept her at her job. Since leaving Samoa in 1951, she had only returned for the briefest stay twice - for her graduation in 1953 and then in mid-1954 to do some observation in Samoan schools. Her only other extended stay away was her year in New Zealand on refresher leave. She related that visit in detail. I repeat the highlights (my abridged translation): 
In January 1965 I went to New Zealand, along with three scholarship students I was escorting, to take a training course and observe teacher training. After many puzzling encounters on the way, we arrived at the Wellington airport. It was a Sunday and there was no-one awaiting us. Fortunately we encountered two young Tokelau men, who first thought us to be Samoans but realised that we were Tokelau when I called out to them: "E mea, olo mai ake (Hey you there, would you please come over here)". The two men took us to the house of some Fakaofo relatives where we rested. Meanwhile my sister and 'brother', having learned of our arrival, had gone to the airport after we had left and were frantically trying to find us. Finally we all got together.

I decided to take my training course at Tokoroa because my older brother, who had been in New Zealand for a number of years, was living there with his wife and 12 kids. When I got to Tokoroa, after several minor mishaps, I began to search for my brother with the help of the Rarotonga family with whom I was living and their friends. They inquired at their work places; I checked the school rolls where I was training, but no-one knew nor could anyone find someone with the surname Lepaio [her brother was using another surname]. It was rumoured that they had shifted to Grey Lynn, so I wrote to the address, but the letter was returned. One afternoon, a week or so later, when I was shopping in the town I recognised my sister-in-law. She immediately took me to their house and finally I found my brother — and he found me - and we stood holding hands and weeping for minutes. It turned out that my brother did not recognise my surname - though he had heard that there was a Tokelau in town who was a teacher with the surname of Mamoe. So I shifted to my brother's house and stayed for four weeks, where my husband, who had come from Tokelau to be with me for Christmas, joined us.

At Christmas Elia and I returned to Wellington and I was assigned to observe teacher's training at the University. I was all set to go, when I heard of the cyclone in Tokelau. I was very alarmed for my children, so upset that I wept day and night. I went to see the people in the Islands Education office and spoke to a Māori man there, asking for arrangements to be made for me to return immediately to Tokelau. When Elia heard about this, he said he would go so I could stay; I said I would go so he could stay. In the end we both decided to return. In two days, on a Friday, the Māori man at Islands Education had everything arranged for us to leave on Monday. We returned to my sister's house and said we were leaving on Monday. She and many others tried to dissuade us because the stores were all closed for the weekend and we could not be properly farewelled and gifted, but we insisted that we were going. So we left taking back nothing. They held the boat for us in Apia and soon we were back in Atafu.

This was Nua's only visit to New Zealand. She did not want to leave Atafu again and she had ignored appeals from sister and others in New Zealand for her to come for a visit now that she was retired. Her response to them was that she wanted to "die in Atafu". 
Nua said of teaching: "It is the most taxing profession (Oi oti te galuega faigata)." She explained that during school hours you were talking all the time, keeping the classroom under control, and looking after the children's health and welfare. After school, you had to put on the blackboard the summary of work for the next day and evaluate the progress of the day just passed. Then you must develop each week a plan of work for the scrutiny of the head teacher. She summed up: "I am unable to neglect any school work (Hẽ mafai ke fakatamala he galuega o te aoga )." Nua maintained, despite educational edicts to the contrary, that mild physical discipline is warranted in some instances. While she admitted that it is better to "teach with words", this was not always enough and you had to slap the schoolchildren's hands to get them to pay attention. She added that in this small community the situation was very different from the usual school situation where the prohibition on physical discipline was quite proper. In Atafu parents and teachers were kin and fellow villagers, and schoolchildren were being taught and disciplined by teachers who were also kin and neighbours, and frequently disciplined them outside school.

There is a further story that Nua told about Dr Logologo's son, who was for many years her teaching colleague. Now it might seem surprising that when the head teacher (the most senior MALE teacher in age and service) was on leave, her childhood wrestling opponent was appointed to act in his place, though he was slightly junior in age and very junior in service to Nua. It was not considered unusual by the NZ education authorities who made decisions in such matters or the male teachers who had come to share their biases. He was the next senior teacher to the head teacher. Nua's story was about an incident when he was acting head teacher.

During this period there was a visit from Mr Philbert of Islands Education to inspect the school, and, as was customary in preparing for such visits, the children in each class were trained to say 'good morning' in English to the visitor. Nua by chance discovered that the acting head teacher had taught his class to greet the visitor 'Good morning, Mr Teapot', and corrected their greeting before it was too late.

The role of the head teacher on these occasions was to go out to the ship, greet the inspector, and escort him to shore. The acting head made much his responsibility for escorting Mr Philbert from the ship to shore. However, in the event, he was so delayed in bringing the school visitor ashore that the schoolchildren had become impatient, had takape 'broken out' of their classrooms and were running around outside, rather than sitting quietly in their places ready to say 'Good morning, Mr Philbert'. Instead of explaining to Mr Philbert that they had been very late coming ashore, the acting head told their visiting inspector that Nua was responsible for the absence of discipline.

Nua laughs—-what else might she have expected. 
Recall that when Sofi Pua left Atafu his status as senior teacher was conferred upon his male replacement, Ioata, although on the grounds of experience and qualifications he was in no way senior to Nua. For the New Zealand education officers in Apia it was inconceivable that a woman might be in charge of a school. Nua remarked that it was the same in Western Samoa with the comment: "Hēki ON te mea tēnei-ke kave he fafine ke pule (It simply was not ON-for a woman to be put in charge (of a school)." Once established that head teachers are men, the situation perpetuated itself. When Ioata returned to Western Samoa in 1956, the eldest male teacher of those who had recently arrived was made head teacher, and when he was on leave, the next eldest, Nua's old wrestling adversary, was appointed acting head teacher, irrespective of the obvious fact that Nua was the longest serving and most experienced teacher. Her male colleagues relied upon her judgement and benefited from her experience, but imbued with the bias of New Zealand educators could never consider that a woman might have senior status at the school. ${ }^{19}$

It is ironic that she started the school, that she devoted 34 years to it, introducing hundreds of Atafu children to schooling - to reading, writing and numbers, and preparing them for the male teachers of the standard classes, yet the only status position she ever held was that of "supervisor of junior classes". ${ }^{20}$ Nonetheless, it was always Nua who was consulted when something was afoot, Nua who was always asked to plan things, to fill in, and she invariably did. As her fellow villagers express it: She was te ivi tū o te aoga (the backbone of the school) for over 30 years - the "mother" of the Atafu School.

Nua retired as a teacher at the age of 60 in 1984. She was asked to go back for a few more years but decided that after all she had done enough. People in Atafu spoke often of what she had done. They had fond memories of their first teacher, they recognised her commitment to teaching and for many she has been a role model, the inspiration for their own achievements.

$$
* * *
$$

Kula's and Nua's stories contain comparable episodes and themes, and placing them side by side serves to highlight their commonalties irrespective of their different life experiences and professional careers. Together they say things about Tokelau people and their culture that a single story would not tell.

When they chose their professional careers, there were really only two fields for Tokelau people to choose from-medicine and teaching. In each of these professions, certain careers were gender specific and the higher status positions were always assigned to men. Women were nurses and men were doctors, and doctors were superior to and much more highly paid than 
nurses. Only women taught very young children, though they might teach older ones too, but women were not in charge of schools as head teachers or principals. These, of course, were unwritten rules of papālagi professions of the time, but they could come to be the unconscious expectations of those that such professionals served. In contemplating their stories and what other Tokelau people say about them, I have asked the question: Did Tokelau people devalue Kula and Nua in relation to their male counterparts because they were women? My answer is unequivocally: No. Even though their remuneration was smaller, even though they were not given the top positions, they were more admired, more highly regarded than their male counterparts. What they did and what they had done is the basis of their renown.

My question above may be widened to ask: Did Tokelau people consider females less able than males? Again, I believe not. Kula and Nua both speak of their mothers as role models, citing their meticulousness, their Christian devotion, their generosity, etc., and they both tell of how their parents, in particular their fathers, urged and encouraged them in their education and careers. In this regard, it is notable that they both had brothers, but their fathers specifically arranged for their daughters' schooling, and were obviously proud of their achievements.

Both of these women took up challenges very early in their careers. Kula virtually ran the health services in Fakaofo and Nukunonu, and established how things must be done in the hospital for staff and patients alike. Nua brought the Atafu School into being, introducing hundreds of children to the skills of reading, writing and numbers. In meeting these challenges, both Kula and Nua engaged enthusiastic community support - support that was given out of respect and admiration, with the knowledge that these two women were devoting themselves to the service of the village and the welfare of all Tokelau. There was never any suggestion that they were seeking esteem and status for themselves.

Kula and Nua were pioneers, and as such role models for those that joined them in their professions. They inspired young women to become nurses, and young women and men to become teachers. They trained them and they counselled them. In this regard they truly are founders. As pioneers and founders, as professional exemplars, as extraordinary people they are celebrated in Tokelau.

\section{ACKNOWLEDGEMENTS}

When the instigators of this volume approached me for a contribution, I demurred because there seemed no way that I could provide a historical portrait given that the historical literature and documentation on Tokelau women is virtually non-existent. 
I had met hundreds, perhaps over a thousand, Tokelau women in the past 30 years or so, and had many close friends among them, so I toyed with the idea of constructing a portrait of a generic Tokelau woman, but then when I tried this I discovered that my knowledge of my friends and acquaintances as individuals precluded this possibilitythe separate "real" women were lively and interesting, but an homogenised "Tokelau woman" was flat. I then proposed a portrait based on Kula's own story - she seemed historical enough to qualify. It was only after I had spoken with Kula, and drafted her story, that I was reminded that Nua was of exactly the same age and decided to create a dual portrait.

Over 15 years have passed since I discussed their lives with Kula and Nua, and since Kula's son and the son of one of Nua's "brothers" of her childhood approved my renditions of their stories. I am grateful to my two subjects for their ready willingness to tell their stories and to the many other Tokelau people who added their recollections and comments.

\section{NOTES}

1. Despite Tokelau appeals, the New Zealand officials had refused to become involved in education, leaving schooling solely to the missions (see Hooper, Huntsman and Kalolo 1991). The Tokelau medical staff, serving all three atolls, consisted of one Fiji-trained "Native Medical Practitioner" and three male "dressers" who dispensed patent medicines and applied bandages.

2. For a much more comprehensive account of the foregoing, see Huntsman and Hooper 1996.

3. For a fuller description of Tokelau gender roles, see Huntsman and Hooper 1975 and 1996: 49-50, 109-121.

4. I knew Kula and Nua for over two decades, and have not only my own experiences with them to draw upon but also the recollections and stories of others. Their own accounts were recorded from conversations with each of them in August 1997. This essay does not incorporate all that they told me, or indeed all that I know about them, but the material included has been passed as correct and appropriate for telling.

5. Logologo Apinelu, a Fiji-trained Native Medical Practitioner, who was "the doctor" for all Tokelau from 1917 until after the Second World War.

6. I have composed this story from Kula's own taped account, supplemented by our earlier and subsequent discussions of the event. Most of the words are Kula's own as I have translated them, since her account and our discussions were in Tokelauan, except for some medical queries on my part and clarification on hers. No anonymity is compromised here, since the essence of the story is well known in Tokelau and indeed beyond. Nonetheless, I have avoided personal names of those involved, aside from Kula of course.

7. The story of the mysterious disappearance of the Joyita at the end of 1955 and its rediscovery after five and a half weeks "drifting and waterlogged, without any trace" of her crew or passengers will not be retold here (see Matagi Tokelau 1991: 131-33, McKay 1968: 152-55, Wright 2002). 
8. In 1971 I had firsthand experience of Kula's resourceful coping. Unexpectedly and unprepared she had been ordered to remain in Nukunonu because the doctor there was very ill and had to leave, and there were simultaneous outbreaks of hepatitis and chicken pox. She decided that we would occupy the maternity ward, and that the main ward would be divided by an imaginary line - the chicken pox patients at one end and the hepatitis patients at the other. Kula set down the rules firmly for the mothers and others attending the patients and the infections did not cross that imaginary line. She organised provisioning of the ward; food was provided and prepared in rotation. All this having been settled, Kula dealt with all the regular calls - two deliveries and a miscarriage, numerous cuts and abrasions, and a young man who had drunk unwisely. The hospital was packed, but nonetheless it was a happy and orderly place under Kula's firm control.

9. While Kula had little objection to living and serving in the other atolls, and in fact enjoyed coming to know her kin and the others in Nukunonu and Atafu, these shifts were distressing each time simply because she had to travel by sea. Kula had no problem with small craft on the lagoon, but on large sea-going vessels she experienced extreme seasickness. This was one time that Kula needed others to look after her.

10. When a Tokelau National Council of Women was established in 1986, Kula was at the forefront, moderating and negotiating and generally keeping things on track.

11. Of course there were costs in tuition and fees, and Kula paid most of them out of her small salary, while Logotasi's father made small contributions from time to time. After all, Logotasi was his son and bore his name as his surname. But Kula remained Fiaola, the daughter of her father.

12. He was the second son of Eli Jennings, the reputed "owner" and proprietor of Olohega who had settled there in 1856 (see Hooper 1975). Daniel's elder brother, also named Eli, succeeded his father as proprietor, while Daniel (a.k.a. Tanielu or Misikosi) pursued commercial activities elsewhere that benefited the family enterprise at Olohega.

13. Her mother, Alisa, was a great granddaughter of the first Eli Jennings and Daniel was her father's father's brother. Her father was Heo Samuelu who had been recruited as a labourer at Olohega by Jennings and whose birthplace was Luangiua/Ontong Java. Alisa and Heo had two other children besides Aga: a daughter who married an Atafu man, and a son, Samuelu, whose second wife was Naomi (see Kula's story).

14. One day when the pupils were lined up in the schoolyard, someone threw a stone that hit her in the left eye. Her eye was indeed seriously injured and there was no remedy. When a party of men came from Fakaofo in the late 1930s to work in Samoa in order to raise money for their church, they insisted that the only way her eye would become right was if she returned to stay with her birth-mother's family in Fakaofo, as if the injury was related to some ill-will from her mother's family because they were not recognised. Lepaio utterly rejected this solution, as did Aga and Nua's "parents" in Atafu. 
15. During this period Nukunonu was not included in the government's schooling programme, even though it combined religious and secular education. Following the Second World War Nukunonu benefited from a much improved mission school when Father Alex McDonald responded to the long-expressed desires of the people to establish a "real" school with instruction in Tokelauan and English. This school quickly far surpassed the long established pastors' schools in Atafu and Fakaofo, and so was not superseded by a government school until nearly two decades later.

16. Village or inati distributions, primarily of communal catches of fish, are frequent in Tokelau (see Huntsman and Hooper 1996: 76-83). Everyone in the village, by an elaborate but efficient system of allocation, receives an equal share, except for visitors who receive special portions. Pastors have always been considered visitors, as has the doctor, and the pioneering schoolteachers were considered likewise.

17. Sofi did not regularly speak Tokelauan, but he understood it. Many years later, when he lived in Auckland, he would often attend Tokelau gatherings and speak in Tokelauan.

18. They had come to be at school in Samoa by diverse and often remarkable circumstances. For examples, Nua's childhood wrestling opponent was there because his father was then doctoring in Samoa and Nua's future husband was there because an American serviceman, who had been stationed in Atafu late in the Second World War, paid for his education. That these particular men were selected for teacher training had little to do with their educational achievements. They just happened to have the schooling that qualified them to train as teachers.

19. Nua had retired when a woman was finally appointed principal of the Atafu school. She was the student who had been ordered to Atafu to teach oral English in 1958, and had been recognised as a particularly distinguished student when she was training.

20. Salary inevitably reflects status, and Nua's salary, despite her years of service, was never as high as that of several of her male colleagues.

\section{ABSTRACT}

Two Tokelau women, both born in 1924, were pioneers in the provision of social services (health and education) in the atolls from the early 1950s. Their stories of their lives, supplemented by accounts of their patients, students and colleagues, form the material from which my brief biographies are constructed. They were celebrated in Tokelau, but never fully recognised in the same way by those New Zealand officials who employed and paid them.

Keywords: Tokelau, gender bias, women's roles, schooling, health services

Author contact address: Judith Huntsman, Department of Anthropology, University of Auckland, Auckland, New Zealand. Email: j.huntsman@auckland.ac.nz 
